\title{
Fate of aniline and sulfanilic acid in UASB bioreactors under denitrifying conditions
}

\author{
Raquel Pereira, Luciana Pereira*, Frank P. van der Zee, M. Madalena Alves \\ IBB-Instituto Biotecnologia e Bioengenharia, Centro Engenharia Biológica, Universidade do Minho, Campus de Gualtar, \\ 4710-057 Braga, Portugal
}

\section{A R T I C L E I N F O}

Article history:

Received 31 March 2010

Received in revised form

22 June 2010

Accepted 15 August 2010

Available online 25 August 2010

\section{Keywords:}

Biodegradation

Aromatic amines

UASB bioreactors

Denitrification

\begin{abstract}
A B S T R A C T
Two upflow anaerobic sludge blanket (UASB) reactors were operated to investigate the fate of aromatic amines under denitrifying conditions. The feed consisted of synthetic wastewater containing aniline and/or sulfanilic acid and a mixture of volatile fatty acids (VFA) as the primary electron donors. Reactor 1 (R1) contained a stoichiometric concentration of nitrate and Reactor 2 (R2) a stoichiometric nitrate and nitrite mixture as terminal electron acceptors. The R1 results demonstrated that aniline could be degraded under denitrifying conditions while sulfanilic acid remains. The presence of nitrite in the influent of R2, caused a chemical reaction that led to immediate disappearance of both aromatic amines and the formation of an intense yellow coloured solution. HPLC analysis of the influent solution, revealed the emergence of three product peaks: the major one at retention time $\left(R_{t}\right) 14.3 \mathrm{~min}$ and two minor at $R_{t} 17.2$ and $21.5 \mathrm{~min}$. In the effluent, the intensity of the peaks at $R_{t} 14.3$ and 17.2 min was very low and of that at $R_{t} 21.5 \mathrm{~min}$ increased ( 2 -fold). Based on the mass spectrometry analysis, we propose the structures of some possible products, mainly azo compounds. Denitrification activity tests suggest that biomass needed to adapt to the new coloured compounds, but after a 3 days lag phase, activity is recovered and the final $\left(\mathrm{N}_{2}+\mathrm{N}_{2} \mathrm{O}\right)$ is even higher than that of the control.
\end{abstract}

(c) 2010 Elsevier Ltd. All rights reserved.

\section{Introduction}

Aromatic amines are important industrial chemicals as their major sources in the environment include several chemical industry sectors such as oil refining, synthetic polymers, dyes, adhesives and rubbers, pharmaceuticals, pesticides and explosives (Pollution inventory, England and Wales, The environment Agency, 2003). They range from simplest aniline to highly complex molecules with conjugated aromatic or heterocyclic structures and multiple substituents. Aromatic amines are commonly generated during the biodegradation of azo dyes by microorganisms under anaerobic conditions, resulting from the reductive cleavage of azo bonds $(-\mathrm{N}=\mathrm{N}-)$ (Pinheiro et al., 2004; van der Zee and Villaverde, 2005). As they are difficult to be removed via traditional wastewater treatment and inevitably tend to persist, the potential toxicity of these compounds should be considered in the treatment process (Bor-Yann et al., 2009). Because many different types of sulfonated azo dyes are currently be utilized, a wide variety of sulfonated aromatic amines will be formed under anaerobic conditions that will not easily be biodegraded and will constitute an important part of untreated COD fraction in azo dyes containing wastewater treatment. Aerobic biodegradation of many aromatic amines has been extensively studied (Brown and Laboureur, 1983; Pinheiro et al., 2004; van der Zee and Villaverde, 2005); however, this may not apply to all aromatic amines. It has been demonstrated that especially sulfonated aromatic amines are often difficult to degrade

\footnotetext{
* Corresponding author. Tel.: +351 253604420 .

E-mail address: lucianapereira@deb.uminho.pt (L. Pereira). 0043-1354/\$ - see front matter (c) 2010 Elsevier Ltd. All rights reserved. doi:10.1016/j.watres.2010.08.027
} 
(Razo-Flores et al., 1996; Tan and Field, 2005; Tan et al., 2005). Aromatic amines are commonly not degraded under anaerobic conditions. Among the many different aromatic amines tested, only a few were degraded. Some of them, substituted with hydroxyl or carboxyl group, were degraded under methanogenic and sulphate reducing conditions (Kalyuzhnyi and Skyler, 2000; Razo-Flores et al., 1999b). A drawback of using aerobic treatment, with the aim of degrading aromatic amines from azo dye cleavage, is that many of them are prone to autoxidation once they are exposed to oxygen. Since autoxidation often involves enlargement of the molecules, their biodegradability may consequently be decreased. Alternatively, nitrate, instead of oxygen, can be used as electron acceptor. Indeed, several ecosystems are characterized by lack of oxygen, such as aquatic sediments, stratified lakes, wetlands and some soil horizons. In those environments, microorganisms can utilize compounds like nitrate, iron, sulphate, manganese and carbonate as electron acceptors. It has been reported that at least some aromatic amines can be degraded coupled to nitrate reduction (Hyung-Yell et al., 2000; Wu et al., 2007; Vázquez-Rodríguez et al., 2008). Moreover, it has been observed in previous research at our laboratory that the presence of nitrate does not lead to autoxidation of reduced azo dyes. A further interesting feature of using nitrate is that the first step of denitrification yields nitrite, a compound that has been found to react with aromatic amines, resulting in deamination, thereby yielding aromatics with a higher biodegradation potential (Seymor et al., 2002). Considering the biodegradability of azo dyes in the environment, it is clear that the fate of aromatic amines under denitrifying conditions is of utmost importance.

In this work two UASB bioreactors are operated under denitrifying conditions with nitrate (R1) and a mixture of nitrate and nitrite (R2) as electron acceptors, and the fate of aniline and/or sulfanilic acid is described.

\section{2.}

\section{Materials and methods}

\subsection{Chemicals}

The aromatic amines, Aniline and Sulfanilic Acid (SA), were purchased from Sigma Aldrich at the highest analytic grade purity commercially available (99\%); chemical structures are represented in Fig. 1. Sodium nitrate and sodium nitrite were purchased from Riedel-de-Haën and the chemicals used to prepare the macronutrients solution were purchased from Sigma, Fulka and Panreac. Ammonium acetate and Methanol (MeOH, 99.9\%) for HPLC analysis were obtained from Sigma and Fisher Scientific, respectively.
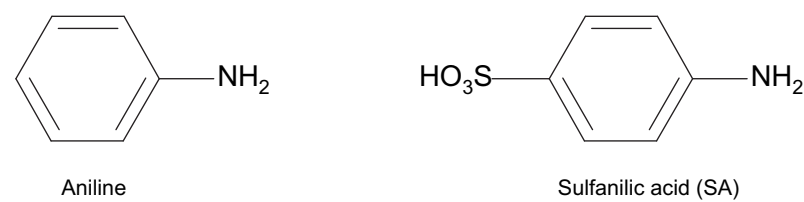

Fig. 1 - Chemical structure of the aromatic amines (Aniline and Sulfanilic acid).

\subsection{Mineral medium}

The basal medium contained (mg L ${ }^{-1}$ ): $\mathrm{NH}_{4} \mathrm{Cl}$ (4750), $\mathrm{KH}_{2} \mathrm{PO}_{4}$ (1300), $\mathrm{CaCO}_{3}$ (270), $\mathrm{MgSO}_{4} \cdot 7 \mathrm{H}_{2} \mathrm{O}$ (500), $\mathrm{FeCl}_{2} \cdot 4 \mathrm{H}_{2} \mathrm{O}$ (2000), $\mathrm{H}_{3} \mathrm{BO}_{3}$ (50), $\mathrm{ZnCl}_{2}$ (50), CuCL $2 \cdot 2 \mathrm{H}_{2} \mathrm{O}$ (38), $\mathrm{MnCl}_{2} \cdot 2 \mathrm{H}_{2} \mathrm{O}$ (409), $\left(\mathrm{NH}_{4}\right)_{6} \mathrm{Mo}_{7} \mathrm{O}_{24} \cdot 4 \mathrm{H}_{2} \mathrm{O}$ (50), $\mathrm{AlCl}_{3}$ (49), $\mathrm{CoCl}_{2} \cdot 6 \mathrm{H}_{2} \mathrm{O}$ (2000), $\mathrm{NiCl}_{2} \cdot 6 \mathrm{H}_{2} \mathrm{O}(92), \mathrm{Na}_{2} \mathrm{SeO}_{3} \mid 5 \mathrm{H}_{2} \mathrm{O}$ (164), EDTA (1000) and $\mathrm{HCl} 37 \%$ $\left(1 \mathrm{~mL} \mathrm{~L}^{-1}\right)$.

\subsection{Experimental set-up}

The experimental installation is schematized in Fig. 2. The two UASB reactors have a diameter and height of 2 and $83 \mathrm{~cm}$, respectively. Reactors were filled with a $5.09 \pm 0.21 \mathrm{gvss}^{-1}$ of granular biomass, with a useful volume of $0.28 \mathrm{~L}$ (Table 1 ). One dual-channel peristaltic pump was used to initially feed the reactors with a constant flow $\left(0.28 \mathrm{~L} \mathrm{~d}^{-1}\right)$. The influent originated from two $5 \mathrm{~L}$ containers, was stored at $4{ }^{\circ} \mathrm{C}$ during the entire process. The reactor's recycle flows were made by a second dual-channel peristaltic pump at a flow rate of 9.6 $\mathrm{L} \mathrm{d}^{-1}$.

\subsection{Aromatic amines biodegradation}

The operation conditions of the two lab-scale UASB, used to study the biodegradation of aniline and sulfanilic acid under different redox conditions, are summarized in Table 1. Both reactors were fed with the same synthetic wastewater containing nutrients and yeast extract $\left(6 \mathrm{~g} \mathrm{~L}^{-1}\right)$, aniline and/or

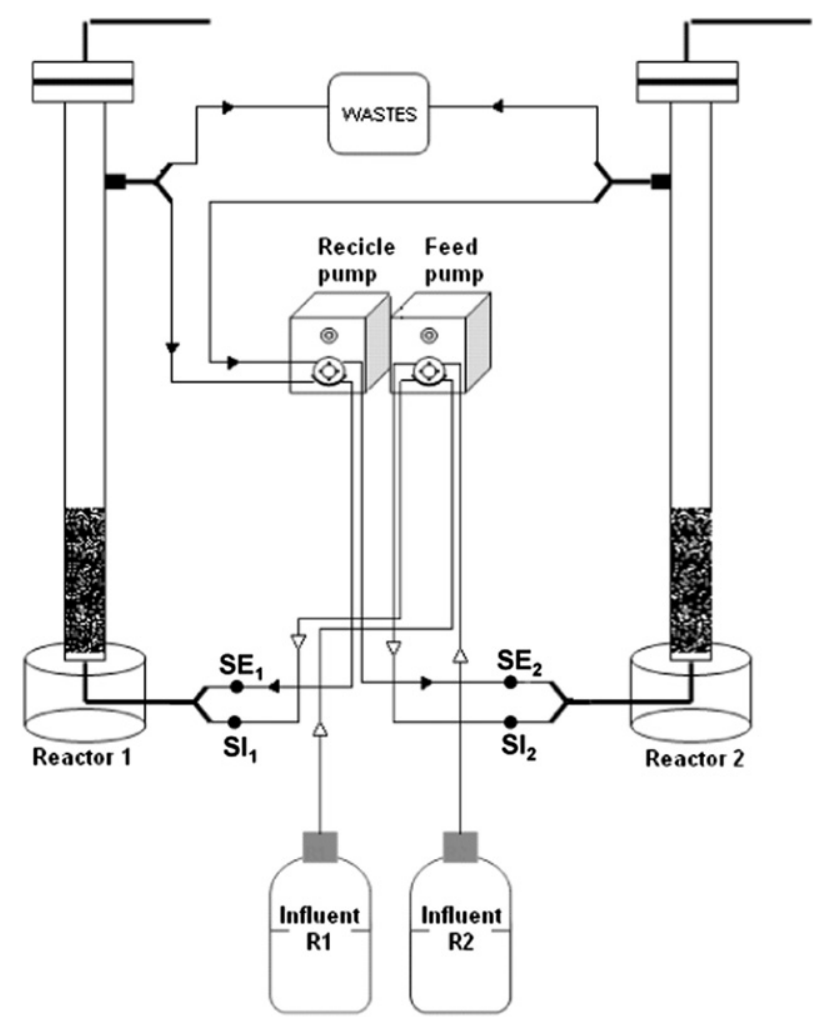

Fig. 2 - Schematic diagram of the experimental set-up. $\mathrm{SI}_{1}$ and $\mathrm{SI}_{2} ; \mathrm{SE}_{1}$ and $\mathrm{SE}_{2}$ - sample withdraw from the influent and effluent of reactors 1 and 2, respectively. 
Table 1 - Operation conditions of the UASB reactors.

Reactor 1 Reactor 2

$\begin{array}{lll}\text { Volume reactor }(\mathrm{L}) & 0.28 & 0.28 \\ \text { Upflow velocity }\left(\mathrm{m} \mathrm{h}^{-1}\right) & 1.00 & 1.00 \\ \text { Flow rate }\left(\mathrm{L} \mathrm{d}^{-1}\right) & 0.28 & 0.28 \\ \text { Aromatic Amines }\left(\mathrm{mgCOD}_{\mathrm{C}} \mathrm{L}^{-1}\right) & 100 & 100 \\ \text { VFA }\left(\mathrm{mgCOD} \mathrm{L}^{-1}\right) & 200 & 200 \\ \text { Total COD }\left(\mathrm{mg} \mathrm{L}^{-1}\right) & 300 & 300 \\ \text { Organic loading rate }\left(\mathrm{mgCOD} \mathrm{L}^{-1} \mathrm{~d}^{-1}\right) & 300 & 300 \\ \text { HRT }(\mathrm{h}) & 24 & 24 \\ \text { Nitrate }(\mathrm{mM}) & 7.5 & 6.0 \\ \text { Nitrite }(\mathrm{mM}) & - & 2.5\end{array}$

sulfanilic acid (0.22 mM, corresponding to $\left.50 \mathrm{mg}_{\mathrm{COD}} \mathrm{mL}^{-1}\right)$ and a mixture of volatile fatty acids (VFA: $200 \mathrm{mg}_{\mathrm{COD}} \mathrm{L}^{-1}$ at 1:1:1 COD bases ratio of acetate, propionate and butyrate) as the primary electron donors. The aimed total COD in the influents of both reactors was $300 \mathrm{mg}_{\mathrm{COD}} \mathrm{L}^{-1}$. According to the stoichiometric mass balances of the organic matter conversion under nitrification conditions, the total oxidation of this amount of COD requires $7.5 \mathrm{mM}$ nitrate or $12.5 \mathrm{mM}$ of nitrite. The conditions of both reactors were similar, except that the influent of Reactor 1 was prepared with a stoichiometric concentration of nitrate $(7.5 \mathrm{mM})$ and of the Reactor 2 with a stoichiometric nitrate/nitrite mixture $(6$ and $2.5 \mathrm{mM}$ respectively) rather than with nitrate solely. Nitrite was at lower concentration in reactor 2, for reasons of nitrite toxicity. The different phases of reactor operation (Table 2) reflect the adjustments of three parameters: influent $\mathrm{pH}$, influent VFA concentration and the nature of aromatic amines added. The influent $\mathrm{pH}$ of phase I was set to 7, but in the following phases was lowered to $\mathrm{pH} 4.8$ to prevent that the value inside the reactors rises beyond the upper value of the optimum range ( $\mathrm{pH}$ 7-9) due to the denitrifying process. In phase IIb, the VFA concentration in the influent was increased in response to the relatively high nitrate/nitrite concentration in the reactor effluent during the phases I and IIa. The influent of phase III contained only SA, in order to study the fate of this compound individually. At last, phase IV was characterized by reactors operation in batch mode in the same conditions as of phase III. During the reactor operation, samples of $1 \mathrm{~mL}$ were withdrawn from the influent and effluent every two days and filtered by Acrodisc $0.20 \mu \mathrm{m}$. Amines concentration was monitored by high performance liquid chromatography (HPLC) and nitrite and nitrate by Ion-Chromatography (IC). COD was measured adapting the standard method SM5220C
(APHA, 1989) with the modification of measuring the absorbance at $600 \mathrm{~nm}$ instead of titulation. The $\mathrm{pH}$ was daily monitored in an Orion-Model 720 A pH meter.

\subsection{HPLC analysis}

HPLC analyses were performed in an HPLC (JASCO AS-2057 Plus) using a reverse phase Nucleosil MNC18 $(300 \mathrm{~mm} \times 4.6 \mathrm{~mm}, 5 \mu \mathrm{M}$ particle size and pore of $100 \AA$ from Machenerey-Nagel, Switzerland) column. The following solvent systems were used as mobile phase: solvent A $(\mathrm{MeOH})$, solvent B (Sodium phosphate buffer, $\mathrm{pH}$ 7). Compounds were eluted at a flow rate of $0.8 \mathrm{~mL} \mathrm{~min}^{-1}$ and at room temperature, with a linear gradient of mobile phase from $10 \%$ to $80 \%$ of solvent A, over $45 \mathrm{~min}$. Aniline elution was monitored at $230 \mathrm{~nm}$, sulfanilic acid at $248 \mathrm{~nm}$ and coloured products from R2 at $350 \mathrm{~nm}$. Identification of aromatic amines in the influent and effluent of reactors was achieved by comparing the retention times $\left(R_{t}\right)$ with respective standards ( $R_{t}$ at $3.6 \mathrm{~min}$ and $14.6 \mathrm{~min}$ for SA and Aniline, respectively).

\subsection{Ion Chromatography analysis}

Nitrate and nitrite were monitored using IC-DIONEX with a manual injector with a $25 \mu \mathrm{L}$ loop, a column DIONEX ION PAC AS4A ( $4 \mathrm{~mm} \times 225 \mathrm{~mm}$ ) and an acquisition and treatment of data VarianWS-Worstation program. The regenerated solution used was $\mathrm{H}_{2} \mathrm{SO}_{4}(25 \mathrm{mM})$. Compounds were eluted with a mixture composed of $1.80 \mathrm{mM} \mathrm{Na}_{2} \mathrm{CO}_{3}$ and $1.70 \mathrm{mM} \mathrm{NaHCO}_{3}$

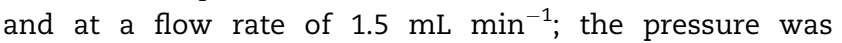
$49.21 \mathrm{Kg} \mathrm{cm}{ }^{-3}$. Concentration of nitrate and nitrite were calculated by the previous determined calibration curves: $C=7.58 \mathrm{e}^{-4} \mathrm{AU}$ and $\mathrm{C}=6.51 \mathrm{e}^{-4} \mathrm{AU}$, respectively; where $\mathrm{C}$ is the concentration $(\mathrm{mM})$ and $A U$ the chromatogram area in arbitrary units.

\subsection{ESI-ion traps analysis}

The ESI-ion trap MS system was an LCQ ion trap mass spectrometer (Thermofinnigan) equipped with electrospray source and run by Xcalibur (Thermofinnigan) version 1.3 software. The following conditions were used in experiments with ESI source in positive and negative mode: temperature of the heated capillary of $350{ }^{\circ} \mathrm{C}$ and source voltage of $4.5 \mathrm{kV}$. Nitrogen was used as sheath gas and auxiliary gas. The sheath and auxiliary gas flow rates were 80 and 20 arbitrary units, respectively. MS was performed in the full scan mode from $\mathrm{m} /$ z 50 to 1100 .

\section{Table 2 - Characterization of the different phases of UASB reactors operation.}

\begin{tabular}{lllcccc} 
Phase & Days & $\mathrm{pH}_{\text {influent }}$ & VFA $\left(\mathrm{mg}_{\mathrm{COD}} \mathrm{L}^{-1}\right)$ & \multicolumn{2}{c}{ Aromatic Amines $(\mathrm{mM})$} & COD Total $\left(\mathrm{mg}_{\mathrm{COD}} \mathrm{L}^{-1}\right)$ \\
\cline { 3 - 5 } & & & & Aniline & SA \\
\hline I & $0-15$ & 7.0 & 200 & 0.22 & 0.22 & 300 \\
IIa & $15-34$ & 4.8 & 200 & 0.22 & 0.22 & 300 \\
IIb & $34-48$ & 4.8 & 300 & 0.22 & 0.22 & 400 \\
IIc & $48-55$ & 4.8 & 400 & - & 0.22 & 500 \\
III & $55-90$ & 4.8 & 300 & & 0.44 & 400 \\
IV & $90-100$ & Operation in batch mode & & \\
\hline
\end{tabular}




\subsection{Batch experiments}

Activity measurements were supported by batch experiments using $70 \mathrm{~mL}$ glass serum bottles with a liquid volume of $60 \mathrm{~mL}$ and a headspace volume of $10 \mathrm{~mL}$. Assays were conducted in triplicate. Tests included series containing the influents and effluents of reactors, a substrate-free control and a control with acetate only. The principle was using nitrate as electron acceptor and acetate as electron donor, at concentrations of $14 \mathrm{mM}$ and $8.75 \mathrm{mM}$ respectively. Vials were supplemented with $5 \mathrm{~mL}$ denitrifying sludge $\left(5.09 \pm 0.21 \mathrm{gvss}^{-1}\right)$, closed with crimp caps and the headspace was flushed with $100 \%$ He. A pressure transducer was used for measuring the pressure every $90 \mathrm{~min}$. The assay was finished when the pressure remained stable. Gas $\left(\mathrm{N}_{2}, \mathrm{~N}_{2} \mathrm{O}\right.$, $\mathrm{CO}_{2}$ and $\mathrm{CH}_{4}$ ) formation was also measured at the end of the test in a Pye Unicam GC-TCD gas chromatograph (Cambridge, England), using a Porapack Q (100-180 mesh) column. Helium was used as carrier gas $\left(30 \mathrm{~mL} \mathrm{~min}{ }^{-1}\right)$ and the temperatures of the injection port and detector were $110{ }^{\circ} \mathrm{C}$ and of the column was $35^{\circ} \mathrm{C}$. The minimum detection limit was $0.1 \mathrm{mM}$. The removal percentage of nitrate/nitrite reduction products is expressed as the ratio (\%) between the $\mathrm{N}_{2}+\mathrm{N}_{2} \mathrm{O}$ produced and $\mathrm{NO}_{3}^{2-}+\mathrm{NO}_{2}^{-}$reduced as the equation: $\% \mathrm{~N}$-recovery $=\left(\mathrm{N}_{2}+\mathrm{N}_{2} \mathrm{O}\right)_{\text {produced }} /\left(\mathrm{NO}_{3}^{2-}+\mathrm{NO}_{2}^{-}\right)_{\text {reduced }} \times 100$.

\section{Results and discussion}

\subsection{Aromatic amine degradation in Reactor 1}

In Fig. $3 \mathrm{~A}$ are represented the results of Aniline and SA concentration in the influent and effluent of reactor 1 , during the six process phases. Aniline removal was high in all the operation phases, although a slight increase was obtained with increasing nitrate consumption. Indeed, the concentrations of nitrate in the effluent at phases I and IIb were higher than the expected, $3.93 \pm 0.70 \mathrm{mM}$ and $3.77 \pm 0.57 \mathrm{mM}$,

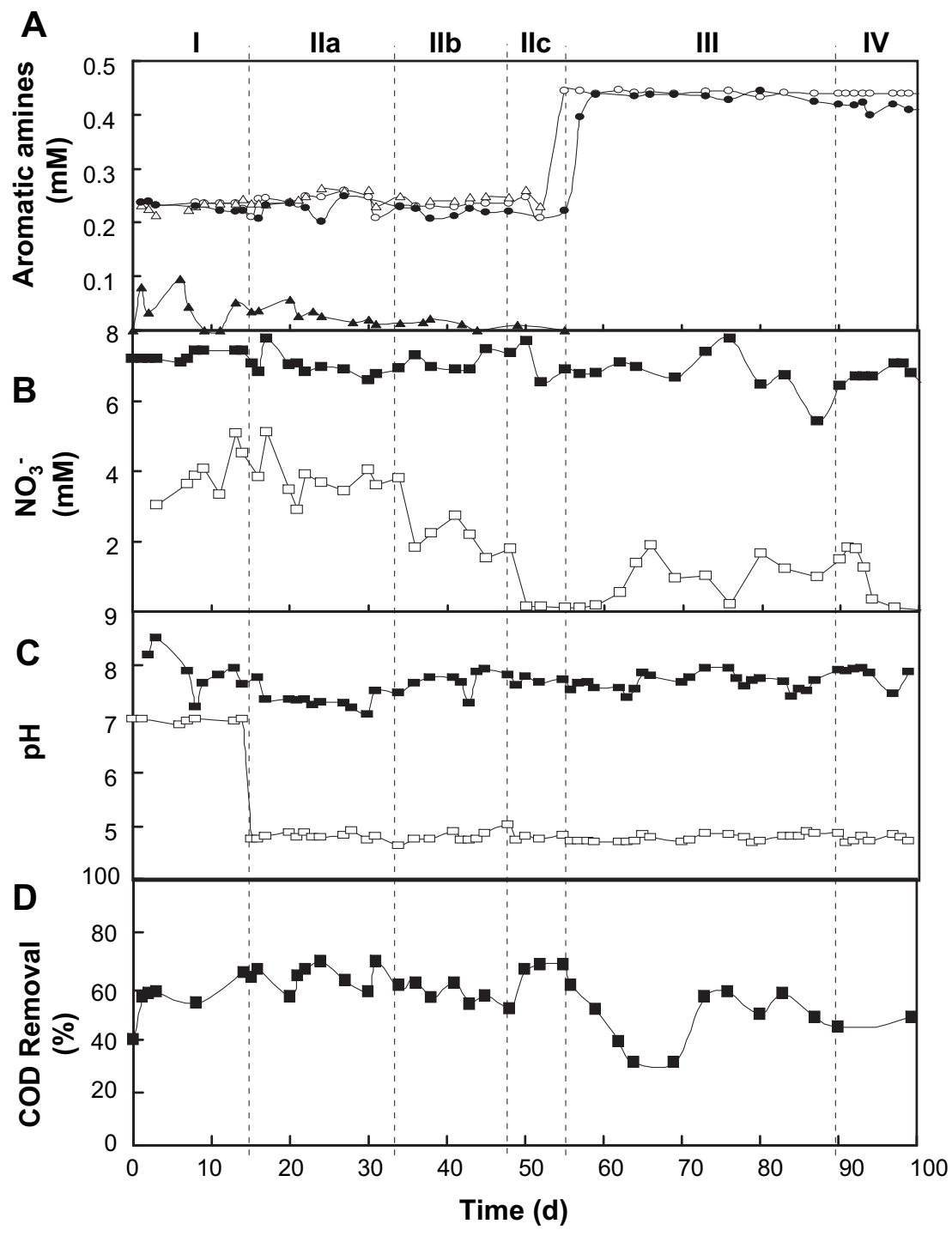

Fig. 3 - (A) Aromatic amines concentration: $(\bigcirc, 0)$ Sulfanilic acid; $(\Delta, \Delta)$ Aniline; (B) Nitrate consumption; (C) pH monitorization and (D) Percentage of COD removal. White markers correspond to the results from the influent and the black to the results from the effluent. 
respectively (Fig. 3B), probably due to a substrate lack. Aniline removal was $80 \%$ in phase I and $88 \%$ in phase IIa. In order to increase nitrate consumption, VFA in the influent was increased from 200 to $300 \mathrm{mg}_{\mathrm{COD}} \mathrm{L}^{-1}$ (phase IIb). Consequently, nitrate concentration in the effluent dropped to $2.03 \pm 0.44 \mathrm{mM}$, corresponding to $\sim 54 \%$ of consumption. At that phase, the aniline removal also increased, to $\sim 95 \%$. In phase IIc, with $400 \mathrm{mg}_{\mathrm{COD}} \mathrm{L}^{-1} \mathrm{VFA}$, the nitrate and aniline removal was almost complete. No SA removal was found in any of the operating reactor phases. An increase of effluent $\mathrm{pH}$ to 8.5 was observed in phase I (Fig. 3C), presumably due to denitrification which is a $\mathrm{pH}$-increasing process (Rust et al., 2000; Karim and Gupta, 2003). Once values higher than the optimum ( $\mathrm{pH} 7-8$ ) can be harmful to the bacteria, the $\mathrm{pH}$ of the influent solution was lowered to 4.8 in phase IIa and onward. From then, the $\mathrm{pH}$ values of the effluent stabilized below $\mathrm{pH}$ 8. The removal of COD in reactor 1 was around $60-70 \%$ in all the phases, with a sharp decrease to $40 \%$ just at the beginning of the phase III (Fig. 3D).

The application of high-rate reactors, such as the UASB reactors, has been proved to be capable of treating various wastewaters bearing toxic aromatic compounds with a high degree of efficiency and stability (Donlon et al., 1996; RazoFlores et al., 1997, 1999a,b; Karim and Gupta, 2003). The first report of a pure culture capable of aniline dissimilation belongs to Schnell and Schink (1991); they have demonstrated that Desulfobacterium aniline was able to catabolize aniline via reductive deamination of 4-aminobenzoyl-CoA, in a process which was linked to sulphate reduction. Since then, many other studies about aniline degradation have been reported. De et al. (1994) have found that aniline is able to be degraded markedly in estuarine sediments under denitrification conditions; Hyung-Yell et al. (2000) demonstrated that the strain HY99, a novel microorganism capable of aerobic and anaerobic degradation of aniline, could catabolize aniline under anaerobic conditions linked with nitrate reduction. More recently, Wu et al. (2007) showed the possibility of aniline degradation by microbes in riverbed sediments under denitrifying conditions. As in our work, they have also observed that aniline biodegradation was enhanced by the nitrate consumption. Aniline showed readily biodegradability in denitrifying environments, $60 \%$ in a short time period $(<28$ days), when tested as a model compound to develop a method for measuring the anoxic biodegradability under denitrifying conditions (Vázquez-Rodríguez et al., 2008). Concerning the SA biodegradation less information is available, but it is known that the sulfonic groups in the molecule difficult its degradation; this is due to the, high solubility conferred by those groups preventing the penetration of the aromatic amine through bacterial membranes and, depending on their position relatively to the azo bound, they also confer steric hindrance (Perei et al., 2001; Carvalho et al., 2008). In fact, some reports on aromatic amines degradation have demonstrated that especially sulfonated aromatic amines are often difficult to degrade (Tan et al., 1999, 2000). More recently these authors have found that none of the several sulfonated amines tested was degraded under anaerobic conditions and, under aerobic, only two of them, 2- and 4-aminobenzenesulfonic acid, were mineralized but with inocula sources that were historically polluted with sulfonated aromatic amines (Tan et al., 2005). Successfully cases on SA degradation are those reported by Perei et al. (2001), whom have isolated, from a contaminated site, the aerobic bacterium Pseudomonas paucimobilis, able to degraded it; and by Coughlin et al. (2002), demonstrating the biodegradation of SA by an aerobic bacterial co-culture, during the degradation of the azo dye Acid Orange 7. A recent study about the efficient biodegradation of both aniline and SA is that of Carvalho et al. (2008), the aromatic amines were easily degraded by three different types of aerobic inocula: domestic wastewater and activated sludge from municipal and industrial treatment plant; although, a high lag phase was required for SA, corroborating the idea that SA biodegradation has high specificity.

\subsection{Aromatic amine degradation in Reactor 2}

Curiously, the influent solution of reactor 2, containing nitrite, turned yellow and colour development increased with time, even stored at $4{ }^{\circ} \mathrm{C}$. The UV-vis spectra at all the phases showed a band with $\lambda_{\max }$ at $350 \mathrm{~nm}$ (data not shown). HPLC analysis of the influent solution, revealed a decrease of aniline and SA in the first phase of $45 \%$ and $27 \%$, respectively. In the following phases, aniline in the influent was totally consumed and SA was present at very low concentration (0.02 \pm 0.007 and $0.06 \pm 0.003$ in phase II and III, respectively).

In HPLC chromatograms at $350 \mathrm{~nm}$, three resulting peaks were observed in phase II, the major one at $R_{t} 14.3 \mathrm{~min}$ and two minor at $R_{t} 17.2$ and 21.5 min (Fig. $4 \mathrm{~A}$ ). In the phase I only the peak at $R_{t} 21.5 \mathrm{~min}$ appeared. That difference may be explained by the different $\mathrm{pH}$ in this phase. Indeed, colour development of influent solution was more pronounced after changing the $\mathrm{pH}$ from 7 to 4.8. Finally, in phase III (absence of aniline), no colour products were obtained. A chemical reaction of single and/or both aromatic amines may occur in the presence of nitrite, justifying the vanishing of the aromatic amines from the influent, before entering in the reactor, and the colour formation. Moreover, once no such reaction was observed in the influent of Reactor 1 (prepared without nitrite) it is clear that the nitrite was responsible for the reaction. Although the SA is also consumed, the fact that no colour formation occurs in its absence leads us to conclude that the presence of aniline is crucial for the chemical reaction. Samples from the effluent were also analyzed by UV-vis and HPLC. A decrease of the $\lambda_{\max }$ at $350 \mathrm{~nm}$ was observed and the solution was lighter in colour. In HPLC chromatograms, the peaks at $R_{t} 14.3$ and 17.2 min almost disappeared and the one at $R_{t} 21.5$ min increased $\sim 3$-fold (Fig. 4B). The production of yellow/orange compounds in the growth media of isolated aniline cultures, during the disappearance of aniline under nitrate-reducing conditions, was also observed by O'neill et al. (2000). Although any attempt to detect the products formed was done, they attributed the colour to the probably formation of azo dye by two ways: 1) partial oxidation of one amino group to a nitroso group followed by condensation with an un-oxidised amine and/or 2) formation of a benzene diazonium salt produced by the reaction of one molecule of aniline with nitrite (obtained from the reduction of nitrate) and its coupling with other molecule of aniline in the para position to give $p$-aminoazobenzene. 

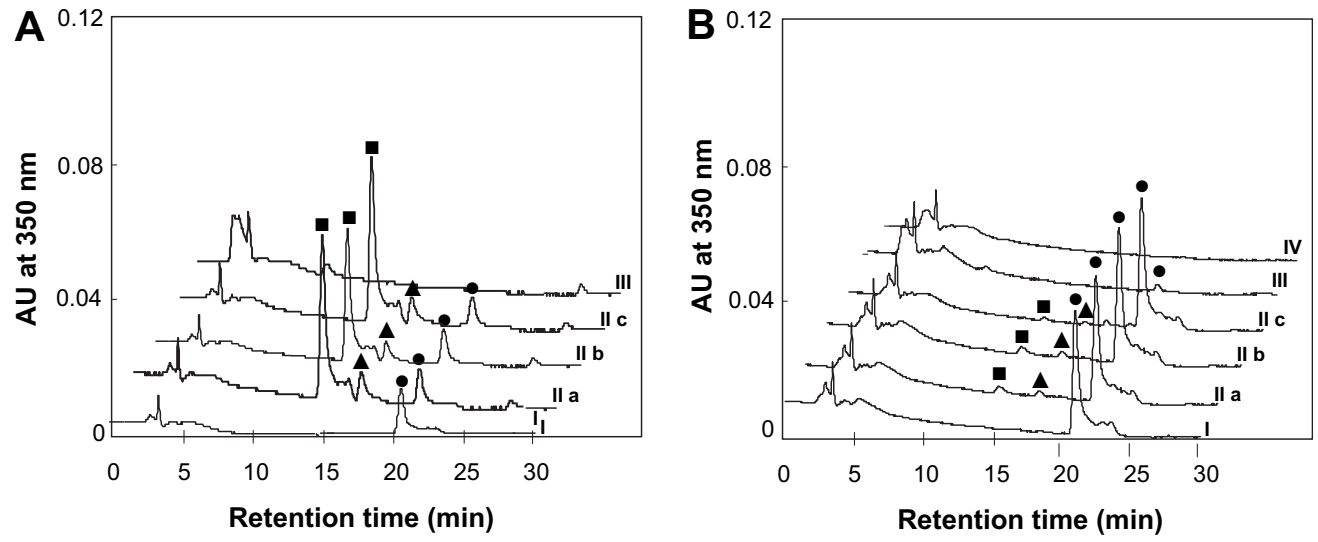

Fig. 4 - HPLC results of the influent (A) and effluent (B) in all the phases of reactor 2 operation. ( $\square) R_{t}$ at $14.2 \mathrm{~min} ;(\Delta) R_{t}$ at $17.3 \mathrm{~min}$ and $(0) R_{\mathrm{t}}$ at $\mathbf{2 1 . 5} \mathrm{min}$.

The COD removal in reactor 2 was lower than in the reactor 1, $\sim 40 \%$.

3.3. Identification of the products formed in the influent of Reactor 2

In an attempt to identify the products of the chemical reaction of aniline and sulfanilic acid with nitrite, in the influent of R2,
MS analysis was done. The mass spectrum in negative mode exhibits peaks with $\mathrm{m} / \mathrm{z}$ 197, 247, 277, 322 and 387 and, in positive ionization, the peaks at $\mathrm{m} / \mathrm{z} 123,219,251,284,342$, 393, 409, 433, 482, 526, 570, 664, 686 and 764 (Fig. 5). The structures for some of the possible products are proposed (Table 3). The ion $\mathrm{m} / \mathrm{z} 123$ may correspond to nitrobenzene. The compound with mass of $218 \mathrm{~g} \mathrm{~mol}^{-1}$ may result from the electrophilic aromatic substitution in the molecule of AS: an

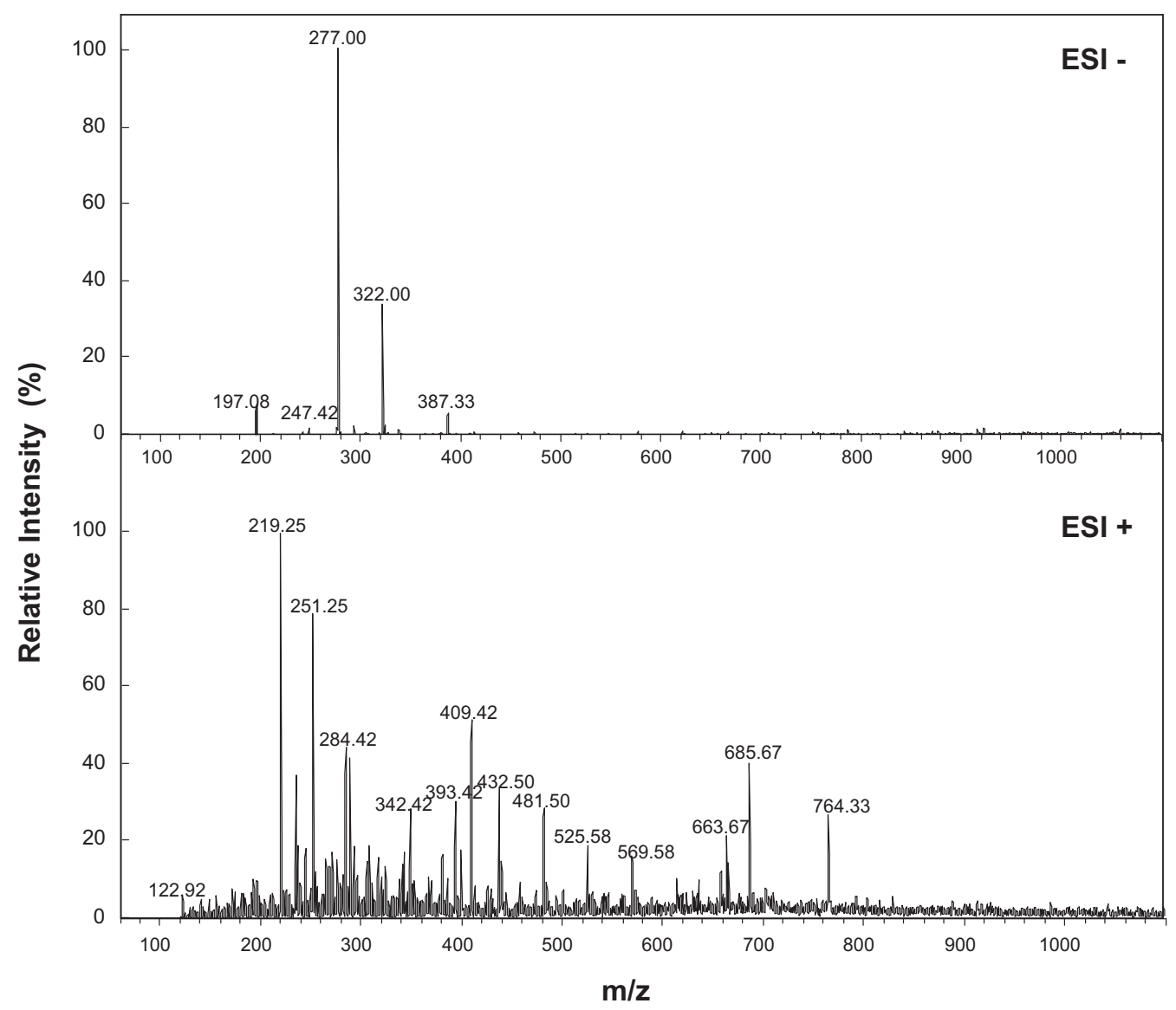

Fig. 5 - Mass spectra of the influent of reactor 2 at the different phases of operation, in negative (ESI-) and positive ionization mode (ESI +). 


\section{Table 3 - Proposed chemical structures for some of the MS detected ions in the influent of reactor 2.}

$m / z(E S I-)$

197

123

122

198

219

218

248

247

277

322

342

341

387

278

323

388
Proposed structure<smiles>O=[N+]([O-])c1ccccc1</smiles><smiles>Oc1ccc(/N=N/c2ccccc2)cc1</smiles><smiles>Nc1ccc(S(=O)(=O)[O-])cc1[N+](=O)[O-]</smiles><smiles>O=[N+]([O-])c1ccc(S(=O)(=O)[O-])cc1[N+](=O)[O-]</smiles><smiles>Nc1ccc(/N=N/c2ccc(OS(=O)(=O)O)cc2)cc1</smiles><smiles>Nc1ccc(/N=N/c2ccc(S(=O)(=O)O)cc2[N+](=O)[O-])cc1</smiles><smiles>O=S(=O)(O)c1ccc(/N=N/c2ccc(S(=O)(=O)O)cc2)cc1</smiles><smiles>O=[N+]([O-])c1cc(S(=O)(=O)O)ccc1/N=N/c1ccc(S(=O)(=O)O)cc1</smiles>

433

432<smiles>O=[N+]([O-])c1cc(S(=O)(=O)O)ccc1/N=N/c1ccc(S(=O)(=O)O)cc1[N+](=O)[O-]</smiles> 
atom of hydrogen from the aromatic system is replaced by a molecule of $\mathrm{NO}_{2}$. The diazotization of this last and of SA can occur (Seymor et al., 2002) to produce the diazonium ions which undergo a coupling reaction with one molecule of aniline to form the compounds with $\mathrm{M}=323 \mathrm{~g} \mathrm{~mol}^{-1}$ and $278 \mathrm{~g} \mathrm{~mol}^{-1}$, respectively, producing a coloured azo chromophore (disazo coupling reaction). Other azo compounds proposed may result from other coupling reactions: between two molecules of sulfanilic acid $\left(\mathrm{M}=341 \mathrm{~g} \mathrm{~mol}^{-1}\right)$; one molecule of the compound with mass 218 and one of AS $\left(\mathrm{M}=388 \mathrm{~g} \mathrm{~mol}^{-1}\right)$; and two molecules of the compound $M=218$ (product with $M=432 \mathrm{~g} \mathrm{~mol}^{-1}$ ). Products with mass 278 and 342 can also result as a fragment of the molecules with mass 323 and 388, respectively, by losses of an $\mathrm{NO}_{2}$ group. The presence of azo compounds in the solution is the responsible of the yellow colour obtained. The formation of the product with $M=198$ (4-phenylazophenol) may be explained by the loss of $\mathrm{SO}_{2}$ from the azo compound formed from coupling of aniline with SA; other possibility is the coupling between one molecule of aniline and one of 4-aminophenol, this last resulted from SA after losing of $\mathrm{SO}_{2}$. Aromatic sulfonates easily undergo loss of $\mathrm{SO}_{2}$ in the negative mode (Suter et al., 1999). No structures could be attributed to the masses of 250, 283, 392, 408, 481, 525, 569, 663, 685 and 763. The higher masses may correspond to oligomers formed from coupling reactions between the lower masses products. It is worth noting that all the reaction products were soluble in the aqueous influent solution; indeed, except for nitrobenzene and 4-phenylazophenol, all the proposed structures have at least one sulfonic group.

\subsection{Batch denitrification activity experiments}

Batch denitrification experiments were performed using the influent (Fig. 6A) and effluent (Fig. 6B) of both reactors. The shape of the curves for the experiments with the influent of R1 is similar to the one of the control with acetate, meaning that no negative effect on the biomass activity was present; nitrate and the aromatic amines at the given concentration in the influent were not inhibitory for the biomass. Kim and Kim (2003) have found that nitrification was not affected by aniline concentrations up to $20 \mathrm{mg} \mathrm{L}^{-1}(0.215 \mathrm{mM})$. O'Neill et al. (2000) have grown aerobic bacterial cultures with aniline as substrate at range of $250-1000 \mathrm{mg} \mathrm{L}^{-1}$ and, in all cases, it was totally consumed and the specific growth rates were not significantly affected. Due to their poor lipophilicity, sulfonated aromatic amines are normally less toxic than the non-sulfonated (Jung et al., 1992; Chen, 2006). Tan et al. (2005) have concluded that sulfonic aromatic amines at concentrations of $100-200 \mathrm{mg} \mathrm{L}^{-1}(0.58-1.16 \mathrm{mM})$ were not toxic to the tested cultures. On the other hand, in batch assays with the influent of R2, a 3 days lag phase is visible, suggesting that products formed by the chemical reaction with nitrite in the influent may exert an initial toxicity. From the results of MS analysis we have proposed the formation of nitro-compounds and it is known that nitro-compounds are more toxic than the corresponding amines (Razo-Flores et al., 1997; Karim and Gupta, 2003). However, we saw that those nitro-compounds coupled to form azo products, probably less toxic. After that initial acclimatization period the activity is recovered and the
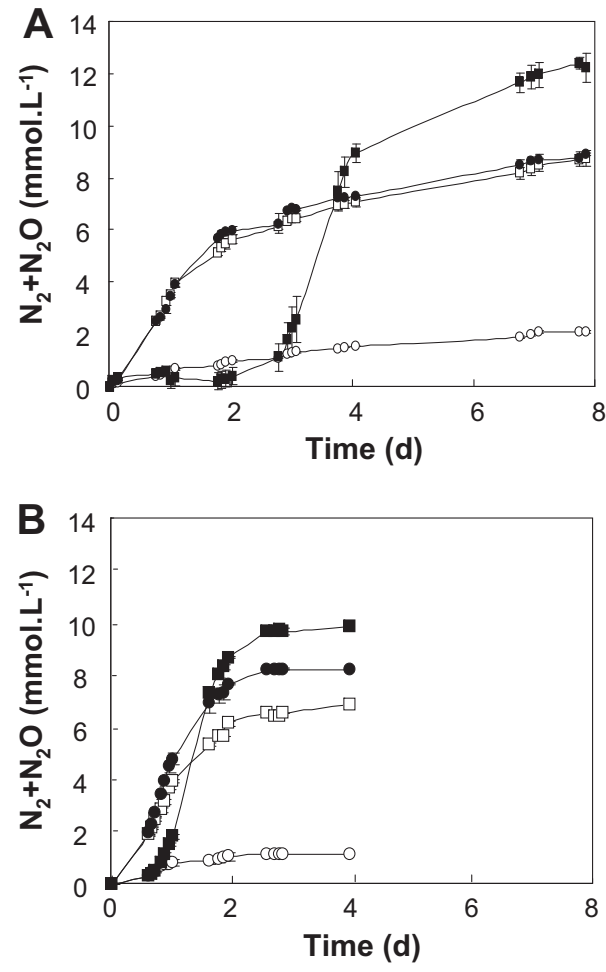

Fig. 6 - Results from denitrifying activity test with the influent (A) and effluent (B) of both reactors: $(\bullet)$, reactor 1; (घ), reactor 2. Controls: $(\square)$, only substrate (acetate) and (O), only biomass.

end value of $\left(\mathrm{N}_{2}+\mathrm{N}_{2} \mathrm{O}\right)$ produced $\left(\sim 12 \mathrm{mmol} \mathrm{L}^{-1}\right)$ is even higher than that of using the influent of R1 and of the control with acetate $\left(\sim 9 \mathrm{mmol} \mathrm{L}^{-1}\right)$, which indicates that the microorganisms are able to transform/degrade the compounds generated and may use them as a carbon source to grow. The higher activity was also evidenced by the higher values of $\mathrm{N}$-recovery percentage in influent of R2, $67 \pm 5 \%$, compared to R1, $49 \pm 1 \%$ and to the control, $50 \pm 1 \%$ (Table 4). In the experiments using the effluent, again similar profiles were obtained for the activity with the effluent of R1 and the control with acetate, although in the first the level of $\left(\mathrm{N}_{2}+\mathrm{N}_{2} \mathrm{O}\right)$ reached was slightly high $\left(\sim 8 \mathrm{mmol} \mathrm{L}^{-1}\right.$ and $7 \mathrm{mmol} \mathrm{L}^{-1}$, respectively). With the effluent of $\mathrm{R} 2$, a lag phase was observed but for a lower period than the obtained with the influent, less than 1 day, and the level of $\left(\mathrm{N}_{2}+\mathrm{N}_{2} \mathrm{O}\right)$ produced at the end was also lower $\left(\sim 10 \mathrm{mmol} \mathrm{L}^{-1}\right)$. The values of $\mathrm{N}$ recovery are similar for both assays with the effluent $(51 \pm 2 \%$ with R1 effluent and $57 \pm 1$ with R2 effluent). The results hint

\begin{tabular}{|c|c|c|}
\hline & \multicolumn{2}{|c|}{ N-recovery \% } \\
\hline & Influent & Effluent \\
\hline Reactor 1 & $49 \pm 1$ & $51 \pm 2$ \\
\hline Reactor 2 & $67 \pm 5$ & $57 \pm 1$ \\
\hline Control with acetate & $50 \pm 1$ & \\
\hline
\end{tabular}


that some detoxification of the coloured products formed in the influent of R2 occurs upon the treatment in the reactor. No $\mathrm{CH}_{4}$ and $\mathrm{CO}_{2}$ production were obtained confirming that denitrification process prevails.

\section{Conclusions}

The results obtained by the continuous UASB reactors operation showed that the proposed system of reactor 1 , using nitrate as electron acceptor, works efficiently to totally remove aniline and $\sim 60-70 \%$ of COD. Sulfanilic acid, with similar structure as aniline but containing an additional sulfonic group, was not degraded in any of the operation phases.

The presence of nitrite in the influent of reactor 2 caused a chemical reaction that led to an yellow colour solution development. Both aromatic amines were consumed and 3 new peaks appeared in the HPLC chromatograms at $350 \mathrm{~nm}$ : a major one at $R_{t} 14.3 \mathrm{~min}$ and two minors at $R_{t} 17.2$ and $21.5 \mathrm{~min}$. A decrease of the colour solution was observed after entering the reactor. In the effluent, the peaks at $R_{t}$ 14.3 and $17.2 \mathrm{~min}$ were very low and the one at $R_{t} 21.5$ increased, being the main one. The overall COD removal in this reactor was lower ( 40\%). Some inhibitory effects by the chemically formed products should not be excluded; although, denitrification activity tests suggest that some detoxification occurs upon the treatment in the reactor. Indeed, with the influent solution, a 3 days lag phase was observed, but after that period higher $\left(\mathrm{N}_{2}+\mathrm{N}_{2} \mathrm{O}\right)$ concentration than in the control was obtained, corroborating the idea that products formed were consumed/degraded after biomass acclimatization.

\section{Acknowledgement}

This work was supported by the PTDC/AMB/69335/2006 project grants. Luciana Pereira holds a Post-Doc fellowship (SFRH/BPD/20744/2004) and Raquel Pereira holds a fellowship (SFRH/BPD/39086/2007) from Fundação para a Ciência e Tecnologia.

\section{R E F E R E N C E S}

APHA, 1989. Standard Methods for the Examination of Water and Wastewater, seventeenth ed. American Public Health Editions Association, Washington DC.

Bor-Yann, C., Lin, K.-W., Wang, Y.-M., Yen, C.-Y., 2009. Revealing interactive toxicity of aromatic amines to azo dye decolorizer Aeromonas hudrophila. J. Hazard Mater. 166, 187-194.

Brown, D., Laboureur, P., 1983. The aerobic biodegradability of primary aromatic amines. Chemosphere 12, 405-414.

Carvalho, M.C., Pereira, C., Gonçalves, I.C., Pinheiro, H.M., Santos, A.R., Lopes, A., Ferra, M.I., 2008. Assessment of the biodegradability of a monosulfonated azo dye and aromatic amines. Int. Biodeterior. Biodegrad. 62, 96-103.

Chen, B.-Y., 2006. Toxicity assessment of aromatic amines to Pseudomonas luteola: chemostat pulse technique and dose-response analysis. Process Biochem., 1529-1538.
Coughlin, M.F., Kinkle, B.K., Bishop, P.L., 2002. Degradation of acid orange 7 in aerobic biofilm. Chemosphere 46, 11-19.

De, M., O'Connor, O., Kosson, D., 1994. Metabolism of aniline under different anaerobic electron-accepting and nutritional conditions. Environ. Toxicol. Chem. 13, 233-239.

Donlon, B.A., Razo-Flores, E., Lettinga, G., Field, J.A., 1996. Continuous detoxification, transformation, and degradation of nitrophenols in Upflow Anaerobic Sludge Blanket (UASB) reactors. Biotechnol. Bioeng. 51, 439-449.

Hyung-Yell, K., Jerome, J.K., Kye-Heon, O., 2000. Characterization of a strain HY99, a Nobel microorganism capable of aerobic and anaerobic degradation of aniline. FEMS Microbiol. Lett. 190, 215-221.

Jung, R., Steinle, D., Anliker, R., 1992. A compilation of genotoxicity and carcinogenicity data on aromatic aminosulphonic acids. Food Chem. Toxicol. 30, 635-660.

Kalyuzhnyi, S., Skyler, V., 2000. Biomineralisation of azo dyes and their breakdown products in anaerobic-aerobic hybrid and UASB reactors. Water Sci. Technol. 41, 23-30.

Karim, K., Gupta, S.K., 2003. Continuous biotransformation and removal of nitrophenols under denitrifying conditions. Water Res. 37, 2953-2959.

Kim, S.-S., Kim, H.-J., 2003. Impact and Threshold concentration of toxic materials in the stripped gas liquor on nitrification. Korean J. Chem. Eng. 20.

O'neill, F.J., Brownley-Challenor, K.C., Greenwood, R.J., Sknapp, J.S. , 2000. Bacterial growth on aniline: implications for the biotreatment of industrial wastewater. Water Res. 34, 4397-4409.

Perei, K., Rakhely, G., Kiss, I., Poliak, B., Kovaks, K.L., 2001. Biodegradation of sulfanilic acid by Pseudomonas paucimobilis. Appl. Microbiol. Biotechnol. 55, 101-107.

Pinheiro, H.M., Touraud, E., Thomas, O., 2004. Aromatic amines from azo dye reduction: status review with emphasis on direct UV spectrophotometric detection in textile industry wastewaters. Dyes Pigm. 61, 121-139.

Razo-Flores, E., Donlon, B.A., Field, J.A., Lettinga, G., 1996. Biodegradability of N-substituted aromatics and alkylphenols under methanogenic conditions using granular sludge. Water Sci. Technol. 33, 47-57.

Razo-Flores, E., Donlon, B.A., Lettinga, G., Field, J.A., 1997. Biotransformation and biodegradability of N-substituted aromatics in methanogenic granular sludge. FEMS Microbiol. Rev. 20, 525-538.

Razo-Flores, E., Lettinga, G., Field, J.A., 1999a. Biotransformation and biodegradation of selected nitroaromatics under anaerobic conditions. Biotechnol. Prog. 15, 358-365.

Razo-Flores, E., Smulders, P., Prenafeta-Bold, F., Lettinga, G., Field, J.A., 1999b. Treatment of anthranilic acid in an anaerobic expanded granular sludge bed reactor at low concentrations. Water Sci. Technol. 40, 187-194.

Rust, C.M., Aelion, C.M., Flora, J.R.V., 2000. Control of pH during denitrification in subsurface sediment microcosms using encapsulated phosphate buffer. Water Res. 34, 1447-1454.

Schnell, S., Schink, B., 1991. Anaerobic aniline degradation via reductive deamination of 4-aminobenzoyl-CoA in Desulfobacterium anilini. Arch. Microbiol. 155, 183-190.

Seymour, E.H., Lawrence, N.S., Pandurangappa, M., Compton, R.G., 2002. Indirect electrochemical detection of nitrite via diazotization of aromatic amines. Microchim. Acta 140, 211-217.

Suter, M.J.-F., Riediker, S., Giger, W., 1999. Selective determination of aromatic sulfonates in landfill leachates and groundwater using microbore liquid chromatography coupled with mass spectrometry. Anal. Chem. 71, 897-904.

Tan, N.C.G., Prenafeta-Boldú, F.X., Opsteeg, J.L., Lettinga, G., Field, J.A., 1999. Biodegradation of azo dyes in coculture of anaerobic granular sludge with aerobic aromatic amine 
degrading enrichment cultures. Appl. Microbiol. Biotechnol. 51, 865-871.

Tan, N.C.G., van Leeuwen, A., van Voorthuinzen, E.M., Slenders, P., Prenafeta-Boldú, F.X., Temmink, H., Lettinga, G., Field, J.A., 2005. Fate and biodegradability of sulfonated aromatic amines. Biodegradation 16, 527-537.

Tan, N.C.G., Field, J.A., 2005. Biodegradation of sulfonated aromatic compounds. In: Environmental Technologies to Treat Sulfur Pollution Principles and Engineering. IWA Publishing, London, pp. 377-392.
Van der Zee, F., Villaverde, S., 2005. Combined anaerobic-aerobic treatment of azo dyes - a short review of bioreactors studies. Water Res. 39, 1425-1440.

Vázquez-Rodríguez, G.A., Beltrán-Hernández, R.I., LuchoConstantino, C.A., Blasco, J.L., 2008. A method for measuring the anoxic biodegradability under denitrifying conditions. Chemosphere 71, 1363-1368.

Wu, Y.-G., Hui, L., Li, X., Zhang, Y.-Z., Zhang, W.-C., 2007. Degradation of aniline in Weihe riverbed sediments under denitrification conditions. J. Environ. Sci. Health Part A 42, 413-419. 